\title{
Influence of heat treatment on the nutrient composition and physicochemical characteristics of Adlai (Coix Lachryma-Jobi L.) and Obatanpa cross Lagkitan (OxL) corn variety (Zea Mays L. 'Los Baños Lagkitan')
}

\author{
${ }^{1 * \text { Magpantay, Jr., R.L., }}{ }^{2}$ Barrion, A.S.A., ${ }^{3}$ Dizon, E.I. and ${ }^{2}$ Hurtada, W.A. \\ ${ }^{1}$ Department of Nutrition and Dietetics, College of Science, Polytechnic University of the Philippines, Sta. \\ Mesa, Manila 1016 \\ ${ }^{2}$ Institute of Human Nutrition and Food, College of Human Ecology, University of the Philippines Los \\ Baños, College, Laguna 4031 \\ ${ }^{2}$ Institute of Food Science and Technology, College of Agriculture, University of the Philippines Los \\ Baños, College, Laguna 4031
}

\author{
Article history: \\ Received: 3 August 2020 \\ Received in revised form: 24 \\ August 2020 \\ Accepted: 27 September 2020 \\ Available Online: 31 \\ December 2020 \\ Keywords: \\ Adlai (Coix lachryma-jobi \\ L.), \\ Corn, \\ Nutritive value, \\ Heat treatment, \\ Retortable pouches
}

\section{DOI:}

https://doi.org/10.26656/fr.2017.5(1).420

\begin{abstract}
The study aimed to investigate the effect of heat treatments on the proximate composition, caloric value, carbohydrate profile and physicochemical characteristics of Adlai and Obatanpa cross Lagkitan corn variety (OxL). Different percentages of Adlai were incorporated to OxL corn and sensory evaluation revealed that $90 \%$ adlai: $10 \%$ OxL corn blend was the most acceptable proportion. The raw, boiled and canned pure adlai, pure OxL corn and the most acceptable adlai-corn blend were used in the study. Results showed that after boiling, all samples fell under the soft gel consistency category (65-100 $\mathrm{mm})$ and have a high gelatinization temperature $\left(>74^{\circ} \mathrm{C}\right)$. In adlai, OxL corn and adlaicorn blend samples, values of moisture and crude fat increased significantly $(\mathrm{p}<0.05)$ from raw to heat-treated samples (boiling and canning), while those of crude protein, crude fiber, total ash and carbohydrate significantly decreased $(p<0.05)$. The energy content $(\mathrm{kcal} / 100 \mathrm{~g})$ was highest in all raw samples while boiling and canning led in a significant $(p<0.05)$ decrease. Moreover, there is a significant $(p<0.05)$ reduction in starch and amylose content of all raw samples after boiling and further decreased by canning. However, the values of moisture, crude fat, total ash, carbohydrates, caloric value, starch and amylose for boiled and canned samples were not significantly $(p>0.05)$ different. Overall, heat treatment significantly reduced the nutritional value of adlai, OxL corn and adlai-corn blend.
\end{abstract}

\section{Introduction}

Coix lacryma-jobi L. also known as Adlai belongs to the family Poaceae or the grasses, the same family to which wheat, corn, and rice belong. It is considered as one of the native crops consumed as food in the Philippines. Also, adlai is cultivated as a cereal in some parts of Asia. As a food source, adlai is as versatile as rice. It can be cooked and processed as the main ingredient for delicacies. The grain can be ground into flour and used to make bread, pasta, and porridge (Domingo, 2016). In Taiwan, adlai is prepared as a milk substitute (Coludo and Janairo, 2015). The pounded kernel is also made into a sweet dish by frying and coating with sugar. It can also be husked and eaten as it is just like peanuts. In the Philippines, adlai is being promoted by the government because of its high protein content and it contains calcium, phosphorus, iron, thiamine, riboflavin and niacin. It is also easy to plant and needs fewer requirements, like irrigation, than that of rice. Furthermore, it can be harvested in a short span of time.

Corn (Zea mays L.), on the other hand, have different varieties including what are locally called obatanpa corn and lagkitan corn. Obatanpa which is a Quality Protein Maize (QPM), is a nutritious and potential health food which contains B-vitamins, phenolic compounds, and essential amino acid (lysine and tryptophan) (de Guzman 2008). Meanwhile, Lagkitan corn or Composite 2 is open-pollinated, glutinous, and yields 6.5 tons per hectare. This variety is for table use with excellent eating quality. (Dela Cruz 2002). The Institute of Plant Breeding at University of 
the Philippines Los Baños developed a high-yielding white corn variety called OxL corn. This breed of Obatanpa and Lagkitan is produced to obtain the size of Obatanpa and to have the excellent eating quality of Lagkitan which has a soft texture.

Heat treatment can lead to improvements in, or damage to, the nutritional composition of foods (Chukwu et al., 2010; Oghbaei and Prakash, 2016). Raw cereals are generally inedible and require cooking. One of the most common ways of consuming cereals is boiling in water. Boiling decreases the amount of nutrients but it can increase digestibility and bioavailability (Chukwu et al., 2010). Canning typically involves the heating of lowacid foods such as cereals at $121^{\circ} \mathrm{C}$, with the goal of eliminating all mesophilic microorganisms, as well as spores of Clostridium botulinum, leaving the product 'commercially sterile' (Murano, 2014). In Japan and USA, cereals are steamed, sealed and sterilized, and then served to military (Juliano, 1993). The use of retortable pouches is economical (Varalakshmi et al., 2014) and may result in a fresher-tasting food (Cox et al., 2006) and nutrient retention (Rizvi and Acton, 1982) compared to tin cans.

The study aimed to determine the effects of boiling and canning on the proximate composition, caloric value, carbohydrate profile and physicochemical characteristics of Adlai, OxL corn and adlai-corn blend.

\section{Materials and methods}

\subsection{Raw materials}

Tapol variety of Adlai was obtained from Southern Tagalog Integrated Research Center, Marawoy, Lipa, Batangas City, Philippines while OxL corn grits were obtained from the Institute of Plant Breeding, University of the Philippines Los Banos, Laguna, Philippines. Retortable pouches (ITDI-DOST, Philippines) of size 18 $\mathrm{cm} \times 10 \mathrm{~cm}$ having a 4 layer configuration of $12 \mu \mathrm{m}$ polyethylene terephthalate, $9 \mu \mathrm{m}$ aluminum, $15 \mu \mathrm{m}$ oriented polyamide, $70 \mu \mathrm{m}$ polypropylene and the total thickness of $106 \mu \mathrm{m}$ which can withstand the retort condition of $121^{\circ} \mathrm{C}$ were used as the packaging material.

\subsection{Selection of adlai and corn blend}

Preliminary study was conducted to determine the most acceptable adlai:OxL corn blend. Eleven combinations of adlai:OxL corn (100:0, 90:10, $80: 20,70: 30,60: 40,50: 50,40: 60,30: 70,20: 80,10: 90$ and $0: 100)$ were subjected to sensory evaluation using a 9-point hedonic scale. The procedure cited by Mabesa (1986) in setting up a sensory evaluation was followed. About 5 grams or one teaspoon of cooked adlai:OxL blend was served warm in a small plastic cup containers. Samples were coded using three digit numbers and the order of presentation to panelists was randomized. Also, distilled water was provided to the evaluators to cleanse the pallet. Results showed that $90 \%$ adlai: $10 \%$ OxL corn was the most acceptable combination in terms of aroma, flavor, texture and over-all acceptability.

\subsection{Sample preparation and canning treatment}

The sample preparation and canning treatment were done at the Department of Science and Technology Industrial Technology Development Institute (DOSTITDI), Philippines. Samples were washed using distilled water to remove dirt and then cooked with chicken stock (170 ml stock/100 g sample) in an electric rice cooker. When cooked, to avoid any possible sources of contamination, $150 \mathrm{~g}$ of the samples were filled in retortable pouch then sealed using a band sealer with hot and cold compressor. After sealing, samples were placed in a horizontal autoclave machine and sterilized to $121^{\circ} \mathrm{C}$ at 15 psi for 15 mins. The commercial sterility test was conducted to guarantee the microbiological control of canned food, as described by Zamora (2013). Cooked Meat Medium (CMM) and Tryptone broth (TB) was used to identify any anaerobic microorganisms' activities after sterilization process. After the incubation period of 5 days, the test tubes were examined. The obtained qualitative results were based on a visual evaluation of the turbidity of the medium and gas formation. Afterwards, gram staining was performed.

\subsection{Determination of nutritional value and physicochemical properties}

Raw, boiled and canned samples of the adlai. OxL corn and adlai-corn blend were tested. Water absorption and solubility gel consistency and gelatinization were measured as described in Testing Manual for Rice (Rice Technical Working Group, 1997). Samples were analyzed, in triplicates, for the proximate composition (moisture content, crude fat, crude protein, total ash, and nitrogen-free extract) following the procedure prescribed in AOAC (Horwitz and Latimer, 2005). Starch content was determined using the anthrone method while the amylose content was determined using a colorimetric assay by Williams et al. (1958).

\subsection{Statistical analysis}

All gathered data were analyzed using One-way Analysis of Variance (ANOVA) and Tukey's studentized range test at 5\% significance level, if applicable. 
Table 1. Physicochemical properties of boiled adlai, OxL corn and adlai-corn blend

\begin{tabular}{|c|c|c|c|c|c|}
\hline \multirow{2}{*}{ Samples } & \multirow{2}{*}{ Gel temperature } & \multicolumn{2}{|c|}{ Gel consistency } & \multirow{2}{*}{ WAI (\%) } & \multirow{2}{*}{ WSI (\%) } \\
\hline & & Measure $(\mathrm{mm})$ & Classification** & & \\
\hline Adlai & & 100 & Soft & $1.15^{\mathrm{a}}$ & $0.02^{\mathrm{a}}$ \\
\hline OxL corn & $\operatorname{High}\left(>74^{\circ} \mathrm{C}\right)$ & 95 & Soft & $0.94^{\mathrm{b}}$ & $0.04^{\mathrm{a}}$ \\
\hline Adlai-corn blend & & 99 & Soft & $1.03^{\mathrm{a}}$ & $0.28^{\mathrm{a}}$ \\
\hline
\end{tabular}

Values are expressed as mean \pm standard deviation (triplicates). Means bearing different superscripts in columns are significantly different. ( $\mathrm{p} \leq 0.05)$.

** $\operatorname{soft}(61-100 \mathrm{~mm})$, medium $(41-60 \mathrm{~mm})$ and hard $(25-40 \mathrm{~mm})$

\section{Results and discussion}

\subsection{Physicochemical properties}

The physical appearance of cereals contributes substantially to its quality. Table 1 shows that all samples exhibited soft gel consistency $(61-100 \mathrm{~mm})$. Gel consistency measures the tendency of the cooked cereals to harden after cooling (Asghar et al., 2012). All samples displayed a high gelatinization temperature. This means that samples can be cooked above $74^{\circ} \mathrm{C}$ and grains will exhibit relatively the same behavior during cooking. Water absorption index (WAI) is a measure of the quantity of water absorbed during cooking of cereals. Results showed that adlai and the adlai-corn blend exhibited a higher WAI (\%) value than OxL corn $(\mathrm{p}<0.05)$ which is an indication of high amylose content of adlai (Asghar et al., 2012; Li et al., 2020). Moreover, adlai may expand more and may result to an increase in volume after boiling. On the other hand, there was no significant difference in all samples when it comes to water solubility index (WSI).

\subsection{Nutritional value of adlai and OxL corn}

Heat treatment may affect the nutritional quality of food. Effects of boiling and canning on the proximate composition and caloric value are given in Table 2 . The moisture content of adlai, OxL corn and adlai-corn blend was significantly $(p<0.05)$ increased after boiling and canning, ranging from $3.00 \%$ to $77.24 \%$. The observed increase in moisture in the boiled and canned samples could be attributed to the absorption of cooking water into the endosperm that resulted in swelling and gelatinization of the starch (Christian and Vaclavik, 2010). These results agree with the reported increase in moisture content upon cooking in corn by $42 \%$ (Bradbury and Holloway, 1988) and in adlai (Manning et al., 2017). However, research had shown that low moisture content of food is desirable since it will reduce the activity of microorganisms (Kordylas, 1990). Although, canning process is designed to destroy the most heat-resistant microorganism, specifically the spores of Clostridium botulinum, which can produce a deadly toxin if they sprout and grow under the anaerobic conditions of canned food (MacDonald and Reitmeier, 2017).
The fat content of all the raw samples significantly $(p<0.05)$ increased after boiling and canning. However, values for boiled and canned samples were not significantly ( $>0.05)$ different. In contrary to a study of Budge and Parrish (1999), lipolytic enzymes will be deactivated with heat treatment which resulted in a decrease in the fat content of the food. One of the reasons for the increase in fat content is may be due to the chicken stock that was used in cooking the samples. However, the nutritional content of the chicken stock was not established.

The protein content ranges from $7.42 \%$ to $11.94 \%$. Boiling significantly $(p<0.05)$ decreased the protein content of Adlai, OxL corn and adlai-corn blend by $2.9 \%, 11.45 \%$ and $7.22 \%$, respectively and by $1.2 \%$, $12 \%$ and $7.5 \%$, respectively, after canning $(\mathrm{p}<0.05)$. The decrease in protein is due to the denaturation wherein the hydrogen bonds and the non-polar hydrophobic interactions in proteins are disrupted by heat (Olajide et al., 2011). This observation agreed with findings that proteins in corn were degraded and become more soluble when heated (Chukwu et al., 2010). It was also reported that protein of powdered adlai decreased significantly upon heating (Manning et al., 2017).

Fiber content of processed adlai, OxL corn and adlaicorn blend samples varied significantly between $0.13 \%$, $1.96 \%$ and $0.16 \%$ for boiling, and $0.08 \%, 1.87 \%$ and $0.07 \%$ for canning. The fiber content of canned samples was significantly lower than that of raw and boiled samples. The decrease in crude fiber of cereals is may be due to the breakage of weak bonds between polysaccharide chains and glycosidic linkages in the dietary fiber polysaccharides (Ajala, 2009). The raw samples had significantly higher fiber content than heat treated samples. The same observation was reported by Luithui and Meera (2018) in adlai grain and by Chukwuma et al. (2016) in corn that the fiber content significantly decreases after heating.

In the same way, raw samples had the highest total ash content $(0.38-1.64 \%)$ followed by boiled samples $(0.25-0.41 \%)$ and the least in canned samples $(0.21$ $0.38 \%)$. The reduction in ash content may be due to the leaching of microelements into the cooking water 
Table 2. Effect of boiling and canning on the proximate composition of adlai, OxL corn and adlai-corn blend

\begin{tabular}{|c|c|c|c|c|c|c|c|}
\hline Sample & Moisture (\%) & Fat $(\%)$ & Protein $(\%)$ & Fiber $(\%)$ & Ash (\%) & $\begin{array}{c}\text { Nitrogen free } \\
\text { extract }(\%)\end{array}$ & $\begin{array}{c}\text { Caloric value } \\
\text { (kcal/100 g } \\
\text { sample) }\end{array}$ \\
\hline \multicolumn{8}{|l|}{ Adlai } \\
\hline Raw & $4.16 \pm 0.06^{b}$ & $1.56 \pm 0.09^{\mathrm{b}}$ & $11.94 \pm 1.89^{\mathrm{a}}$ & $0.28 \pm 0.01^{\mathrm{a}}$ & $1.64 \pm 0.05^{\mathrm{a}}$ & $80.42 \pm 1.24^{\mathrm{a}}$ & $383.48^{\mathrm{a}}$ \\
\hline Boiled & $52.23 \pm 2.15^{\mathrm{a}}$ & $1.92 \pm 0.16^{\mathrm{a}}$ & $11.59 \pm 1.21^{\mathrm{b}}$ & $0.13 \pm 0.02^{\mathrm{b}}$ & $0.41 \pm 0.04^{\mathrm{b}}$ & $33.72 \pm 1.14^{\mathrm{b}}$ & $198.52^{b}$ \\
\hline Canned & $51.70 \pm 3.70^{\mathrm{a}}$ & $2.08 \pm 0.12^{\mathrm{a}}$ & $11.45 \pm 0.84^{\mathrm{b}}$ & $0.08 \pm 0.001^{\mathrm{c}}$ & $0.38 \pm 0.06^{\mathrm{b}}$ & $34.31 \pm 2.00^{\mathrm{b}}$ & $201.76^{\mathrm{b}}$ \\
\hline \multicolumn{8}{|l|}{ OxL corn } \\
\hline Raw & $3.00 \pm 0.02^{\mathrm{b}}$ & $0.97 \pm 0.01^{b}$ & $9.53 \pm 0.77^{\mathrm{a}}$ & $2.2 \pm 0.001^{\mathrm{a}}$ & $0.38 \pm 0.78^{\mathrm{a}}$ & $83.92 \pm 0.65^{a}$ & $382.53^{\mathrm{a}}$ \\
\hline Boiled & $72.24 \pm 2.57^{\mathrm{a}}$ & $1.24 \pm 0.02^{\mathrm{a}}$ & $8.43 \pm 0.45^{b}$ & $1.96 \pm 0.17^{\mathrm{b}}$ & $0.25 \pm 0.32^{b}$ & $15.88 \pm 3.07^{\mathrm{b}}$ & $108.40^{\mathrm{b}}$ \\
\hline Canned & $69.36 \pm 5.50^{\mathrm{a}}$ & $1.55 \pm 0.23^{\mathrm{a}}$ & $7.42 \pm 1.15^{\mathrm{c}}$ & $1.87 \pm 0.21^{\mathrm{c}}$ & $0.21 \pm 0.08^{\mathrm{b}}$ & $19.59 \pm 5.52^{b}$ & $121.99^{\mathrm{b}}$ \\
\hline \multicolumn{8}{|c|}{ Adlai-corn blend } \\
\hline Raw & $4.34 \pm 0.47^{\mathrm{b}}$ & $1.21 \pm 0.02^{\mathrm{b}}$ & $11.35 \pm 1.11^{\mathrm{a}}$ & $0.25 \pm 0.01^{\mathrm{a}}$ & $1.40 \pm 1.05^{\mathrm{a}}$ & $81.45 \pm 1.05^{\mathrm{a}}$ & $382.09^{\mathrm{a}}$ \\
\hline Boiled & $55.44 \pm 1.73^{\mathrm{a}}$ & $1.52 \pm 0.15^{\mathrm{a}}$ & $10.53 \pm 0.86^{b}$ & $0.16 \pm 0.04^{\mathrm{b}}$ & $0.31 \pm 0.03^{\mathrm{b}}$ & $32.04 \pm 2.84^{\mathrm{b}}$ & $183.96^{\mathrm{b}}$ \\
\hline Canned & $52.70 \pm 2.70^{\mathrm{a}}$ & $1.85 \pm 0.05^{\mathrm{a}}$ & $9.73 \pm 1.08^{\mathrm{c}}$ & $0.07 \pm 0.01^{\mathrm{b}}$ & $0.26 \pm 0.03^{\mathrm{b}}$ & $35.39 \pm 3.17^{b}$ & $197.13^{b}$ \\
\hline
\end{tabular}

Values are expressed as mean \pm standard deviation (triplicates). Values with the same superscript within the columns are significantly different $(\mathrm{p} \leq 0.05)$. Carbohydrate is measured as nitrogen free extract by difference

(Myrene and D'souza, 2013).

Raw samples had the highest carbohydrate content and caloric value (80.42-83.92\% and 382.09-383.48 kcal, respectively) followed by canned samples (19.59$35.39 \%$ and $121.99-201.76 \mathrm{kcal}$, respectively) while the boiled sample had the least carbohydrate content and caloric value $(15.88-33.72 \%$ and $108-198.52 \%$, respectively). Same observation by Kavitha and Parimalavalli (2014) that raw cereals contained higher carbohydrate content and caloric value than heat-treated samples.

\subsection{Carbohydrate profile}

Processing had a significant impact on the carbohydrate profile of adlai, OxL corn and adlai-corn blend as shown in Table 3 . Boiling led to a significant $(\mathrm{p}<0.05)$ reduction in starch content of aldai, OxL corn and adlai-corn blend by $11.47 \%, 3 \%$ and $11.44 \%$, respectively and by $12.28 \%, 4 \%$ and $12.11 \%$ after canning. Similarly, boiling significantly $(p<0.05)$ decreased the amylose content of all the samples and further decreased by canning. However, starch and amylose values for boiled and canned samples were not significantly $(p>0.05)$ different. Raw samples have significantly $(\mathrm{p}<0.05)$ higher starch and amylose content compared to heat-treated samples. During heat treatment, starch granules are gelatinized and partly solubilized (Pomeranz, 1990; Guillén et al., 2018) and these findings were supported by the study of Tester and Morrison (1993) that corn started swelling at around $40^{\circ} \mathrm{C}$ and leaching of polysaccharides began. Hence, the decrease in starch and amylose may be observed. Same results were detected in the study of Luithui and Meera (2018) where the starch and amylose content of adlai decreases after subjecting to different temperatures.

Table 3. Effect of boiling and canning on carbohydrate profile of adlai, OxL corn, and adlai-corn blend

\begin{tabular}{cccc}
\hline Sample & Starch & Amylose* $^{*}$ & Amylopectin \\
\hline Adlai & & & \\
\hline Raw & $75.70 \pm 1.11^{\mathrm{a}}$ & $26.18 \pm 0.42^{\mathrm{a}}$ & $49.51 \pm 1.32^{\mathrm{a}}$ \\
Boiled & $67.01 \pm 0.58^{\mathrm{b}}$ & $22.53 \pm 0.47^{\mathrm{b}}$ & $44.48 \pm 0.59^{\mathrm{b}}$ \\
Canned & $66.40 \pm 1.8^{\mathrm{b}}$ & $22.48 \pm 0.72^{\mathrm{b}}$ & $43.91 \pm 2.47^{\mathrm{b}}$ \\
\hline OxL corn & & & \\
\hline Raw & $81.15 \pm 0.6^{\mathrm{a}}$ & $20.19 \pm 0.31^{\mathrm{a}}$ & $60.95 \pm 0.92^{\mathrm{a}}$ \\
Boiled & $78.46 \pm 1.04^{\mathrm{b}}$ & $18.12 \pm 0.52^{\mathrm{b}}$ & $60.33 \pm 1.16^{\mathrm{a}}$ \\
Canned & $78.25 \pm 0.7^{\mathrm{b}}$ & $18.04 \pm 0.42^{\mathrm{b}}$ & $60.21 \pm 1.06^{\mathrm{a}}$ \\
\hline Adlai-corn blend & & & \\
\hline Raw & $73.40 \pm 1.00^{\mathrm{a}}$ & $24.73 \pm 0.43^{\mathrm{a}}$ & $48.67 \pm 0.60^{\mathrm{a}}$ \\
Boiled & $65.00 \pm 1.34^{\mathrm{b}}$ & $21.48 \pm 0.42^{\mathrm{b}}$ & $43.52 \pm 1.70^{\mathrm{b}}$ \\
Canned & $64.51 \pm 1.04^{\mathrm{b}}$ & $21.10 \pm 1.23^{\mathrm{b}}$ & $43.41 \pm 0.22^{\mathrm{b}}$ \\
\hline
\end{tabular}

Values are expressed as mean \pm standard deviation (triplicates). Values with the same superscript within columns are significantly different. $(\mathrm{p} \leq 0.05)$. ${ }^{*}$ Waxy $(1-5 \%$ amylose); very low (5-12\% amylose); low (12-20\% amylose); intermediate (20-25\% amylose); high (26-33\% amylose).

\subsection{Commercial sterility test for canning procedure}

Some microorganisms that grow in canned foods do not produce gas and therefore cause no abnormal appearance of the packaging; nevertheless, they cause spoilage of the product. One of the reasons of spoilage is due to retort operations that are faulty because of inaccurate or improperly functioning thermometers, gauges, or controls (Landry et al., 2001). Commercial sterility tests using Cooked Meat Medium (CMM) and Tryptone Broth (TB) were done in canned samples. Results showed that test tubes with CMM and tryptone 
broth did not exhibit turbidity or cloudy appearance. Hence, canned samples are safe from spoilage by thermophilic anaerobes such as $C$. thermobutylicum, $C$. botulinum, $C$. sporogenes, and C. perfringens. There was no presence of any microorganisms after the gramstaining was done.

\section{Conclusion}

The pure adlai, pure OxL corn and the 90\% adlai: $10 \%$ OxL corn were used in the study. Heat treatments were applied to the samples. Boiling made the texture of the cereals soft hence increases acceptability and palatability. Boiling and canning significantly $(p<0.05)$ increased the moisture and fat content but significantly reduced the crude protein, crude fiber, total, carbohydrates, caloric value and carbohydrate profile of adlai, corn and adlai-corn blend. However, the difference between the values of boiling and canning were not significant $(\mathrm{p}>0.05)$.

\section{Conflict of interest}

The authors declare no conflict of interest.

\section{Acknowledgments}

This study was financially supported through the Department of Science and Technology, Science Education Institute - Accelerated Science and Technology Human Resource Development Program Scholarship.

\section{References}

Ajala L. (2009). The Effect of Boiling on the Nutrients and Anti-Nutrients in Two non-Conventional Vegetables. Pakistan Journal of Nutrition, 8(9), 1430-1433 https://doi.org/10.3923/ pjn.2009.1430.1433

Asghar, S., Anjum, F.M., Amir, R.M. and Khan, M.A. (2012). Cooking and eating characteristics of Rice (Oryza sativa L.)-A review. National Institute of Food Science and Technology, University of Agriculture, Faisalabad. Pakistan Journal of Food Sciences, 22(3), 128-132.

Bradbury, J.H. and Holloway, W.D. (1988). Chemistry of Tropical Root Crops: Significance for Nutrition and Agriculture in the Pacific, Australian Centre for International Agricultural Research (ACIAR), Canberra, ACT, Australia. Monograph Series No. 6., p. 201. Melbourne: Australian Centre for International Agricultural Research

Budge, S.M. and Parrish, C.C. (1999). Lipid Class And Fatty Acid Composition Of Pseudo-Nitzschia
Multiseries And Pseudo-Nitzschia Pungens And Effects Of Lipolytic Enzyme Deactivation. Phytochemistry, 52(4), 561-566. https:// doi.org/10.1016/S0031-9422(99)00241-1

Chukwu, O., Orhevba, B. and Mahmood, B. (2010). Influence of Hydrothermal Treatments on Proximate Compositions of Fermented Locust Bean (Dawadawa). Journal of Food Technology, 8(3), 99101. https://doi.org/10.3923/jftech.2010.99.101

Christian, E. and Vaclavik, V. (2010). Essentials of Food Science. 4th ed., p. 41. New York, USA: SpringerVerlag New York.

Codex Alimentarius. (2013). Guidelines for Use of Nutrition and Health Claims. CXG 23-1997. Retrieved from FAO Website: http://www.fao.org/ fao-who-codexalimentarius/sh-proxy/en/? lnk $=1 \&$ url $=$ https $\% 253 \mathrm{~A} \% 252 \mathrm{~F} \%$ 252Fworkspace.fao.org\%252Fsites\%252Fcodex\% 252FStandards $\% 252 \mathrm{FCXG} \% 2 \mathrm{~B} 23-1997 \%$ 252FCXG_023e.pdf

Coludo, F.E and Janairo, G.C. (2015). Effects of Soil Chemistry on the Physico-chemical characteristics of grains of Adlai grown in Bukidnon Philippines. Annals of Tropical Research, 37(1), 26-43. https:// doi.org/10.32945/atr3712.2015

Cox, L., Jun, S. and Huang, A. (2006). Using the Flexible Retort Pouch to Add Value to Agricultural Products. Food Safety and Technology, Vol. 18. USA: Cooperative Extension Service.

De Guzman, C. (2008). Rice composites (rice+corn) as an enriched potential staple. Retrieved from the Republic of the Philippines, Bureau of Agricultural Research website: https://bar.gov.ph/index.php/testarchive/187-december-2008-issue/2271-ricecomposites-rice-corn-as-an-enriched-potential-staple

Dela Cruz, R.T. (2002). New varieties of high-yielding white corn now available-IPB. Retrieved from the Republic of the Philippines, Bureau of Agricultural Research website: https://bar.gov.ph/index.php/testarchive/423-january-2002-issue/4800-jan22-2002new-varieties-of-high-yielding-white-corn-nowavailable-ipb\#: :text=Thus $\% 2 \mathrm{C} \% 20$ the $\%$ 20Institute\%20of\%20Plant,and\%20the\%20DLU\% 20Pearl\%20Sweet.

Domingo, R. (2016). Developing, promoting 'adlai' as alternative staple food. Philippine Daily Inquirer. Retrieved from Business Inquirer website: https:// business.inquirer.net/218105/developing-promotingadlai-as-alternative-staple-food

Guillén, S., Oria, R. and Salvador, M. (2018). Impact of Cooking Temperature on In Vitro Starch Digestibility of Rice Varieties with Different 
Amylose Contents. Polish Journal of Food and Nutrition Sciences, 68(4), 319-325. https:// doi.org/10.2478/pjfns-2018-0001

Horwitz, W. and Latimer, G.W. (2005). Official Methods of Analysis of AOAC International. 18th ed. Maryland: AOAC International.

Juliano, B.O. (1993). Rice in Human Nutrition Books. Retrieved from IRRI website: http:/ books.irri.org/9251031495_content.pdf.

Kavitha, S. and Parimalavalli, R. (2014) Effect of Processing Methods on Proximate Composition of Cereal and Legume flours. Journal of Human Nutrition and Food Science, 2(4), 1051-1055.

Kordylas, J. (1990). Processing and preservation of tropical and sub-tropical foods, p. 109-110. Hampshire, United Kingdom: Macmillian Educational Ltd.

Landry, W., Schwab, A. and Lancette, G. (2001). BAM Chapter 21A: Examination of Canned Foods. Retrieved from FDA website: https://www.fda.gov/ food/laboratory-methods-food/bam-chapter-21aexamination-canned-foods

Li, C., Dhital, S., Gilbert, R. and Gidley, M. (2020). High-amylose wheat starch: Structural basis for water absorption and pasting properties. Carbohydrate Polymers, 245, $116557 . \quad$ https:// doi.org/10.1016/j.carbpol.2020.116557

Luithui, Y. and Meera, M. (2018). Effect of heat processing on the physicochemical properties of Job's tears grain. Journal of Food Measurement and Characterization, 13(1), 874-882. https:// doi.org/10.1007/s11694-018-0001-4

Mabesa, E.L. (1986). Sensory Evaluation of Foods: Principles and Methods, p. 5-10. Philippines: College of Agriculture- University of the Philippines Los Banos.

MacDonald, R. and Reitmeier, C. (2017). Food Processing. Understanding Food Systems. 1st ed. USA: Academic Press. https://doi.org/10.1016/B978 -0-12-804445-2.00006-5

Manning, C., Navarro, R. and Cruz, C. (2017). Nutritional Potential of Coix lachryma-Jobi (Adlai) as a Cereal based Milk Drink. Philippine E-Journals, $4,31-54$.

Murano, E. (2014). Heat Treatment of Foods: Synergy Between Treatments. In Batt, C.A. and Tortorello, M.L. (Eds.) Encyclopedia of Food Microbiology. 2nd ed., p. 181-186. USA: Academic Press. https:// doi.org/10.1016/B978-0-12-384730-0.00161-0

Myrene, R. and D'souza (2013). Effect of Traditional processing Methods on nutritional quality of field bean. Advanced Biomedical Research, 4(3), 29-33.
Oghbaei, M. and Prakash, J. (2016). Effect of primary processing of cereals and legumes on its nutritional quality: A comprehensive review. Cogent Food and Agriculture, 2, $\quad 1136015 . \quad \mathrm{https}$ /// doi.org/10.1080/23311932.2015.1136015

Olajide, R., Akinsoyinu, A.O., Babayemi, O.J., Omojola, A.B., Abu, A.O. and Afolabi, K.D. (2011). Effect of Processing on Energy Values, Nutrient and AntiNutrient Components of Wild Cocoyam (Colocasia esculenta (L.) Schott) Corn. Pakistan Journal of Nutrition, 10(1), 29-34. https://doi.org/10.3923/ pjn.2011.29.34

Pomeranz, Y. (1990). Carbohydrates: Structure of starch granules. In Functional Properties of Food Components. $2^{\text {nd }}$ ed., p. 21-22. New York, USA: Academic Press.

Rizvi, S. and Acton, J. (1982). Nutrient enhancement of thermostabilized foods in retort pouches. Food Technology, 36(4), 105-109.

Rice Technical Working Group (RTWG). (1997). National Cooperative Testing Manual for Rice: Guidelines and Policies. Science City of Muñoz, Nueva Ecija, Philippines: Philippine Rice Research Institute

Tester, R. and Morrison, W. (1993). Swelling and Gelatinization of Cereal Starches. Effects of Amylopectin, Amylose, and Lipids. Cereal Chemistry, 67(6), 551-557.

Varalakshmi, K., Prince, D., Babji, Y. and Rajkumar, R. (2014). Retort Pouch Technology for Ready to Eat Products - An Economic Analysis of Retort Processing plant. IOSR Journal of Agriculture and Veterinary Science, 7(1), 78-84. https:// doi.org/10.9790/2380-07147884

Williams, V.R., Wu, W.T., Tsai, H.Y. and Bates, H.G. (1958). Varietal differences in amylase content of rice starch. Journal of Agricultural and Food Chemistry, 6, 47-48. https://doi.org/10.1021/ jf60083a009

Zamora. (2013). Food Microbiology: Laboratory Manual, p. 67-68. San Pablo City, Laguna, Philippines: Seven Lakes Printing Press. 